\title{
Questions \& Answers: The Migrant Protection Protocols and Immigration Courts in the United States
}

\author{
Thomas Rachko
}

In January 2019, the Trump Administration's Department of Homeland Security (DHS) implemented the Migrant Protection Protocols (MPP), colloquially known as the "Remain in Mexico" program. The MPP is a United States government immigration policy that requires that asylum seekers be returned to Mexico to wait as their claims pend in United States immigration court proceedings. Supporters of the program argued that the policy was a step to strengthen border security and prevent human smuggling and trafficking. However, journalists, human rights organizations, and academics exposed how the policy manufactured a humanitarian crisis and stranded over 70,000 asylum seekers in dangerous Mexican border cities. This article examines the impacts of the MPP on the United States asylum and immigration court system. It explores the implementation of and Trump administration justification for the MPP, analyzes government data and evaluation of the policy, reviews investigative documentation from public reporting by media and nonprofit organizations, and sets forth recommendations for Congress and the Biden Administration to begin to reverse and repair the harms imposed on asylum seekers. Over two years later, the MPP policy is known as one of the Trump Administration's most damaging antiasylum policies putting asylum seekers in harm's way.

\section{https://doi.org/10.4079/pp.v28i0.6}


THOMAS J. RACHKO, JR. is a 2020 graduate of George Washington University with a Master of Public Administration concentrated in Policy Analysis and Program Evaluation. While at the Trachtenberg School, Thomas served as a staff writer for the Brief Policy Perspectives blog and was an associate editor for Volume 27 of the Policy Perspectives journal. He currently serves as a senior program coordinator in the US Program at Human Rights Watch. He graduated from the City University of New York Macaulay Honors College at Hunter College in 2015 with a B.A. in history. Thomas is the grandson of Cuban political asylees and son of a formerly incarcerated returning citizen. 


\section{INTRODUCTION}

On January 25, 2019, the Trump Administration's Department of Homeland Security (DHS) announced the implementation of the Migrant Protection Protocols (MPP) (DHS 2019a). The MPP is a United States government immigration policy that forces asylum seekers to wait in Mexico as their claims pend in US immigration court proceedings. This asylum policy action is also colloquially known as the "Remain in Mexico" program. As of February2021, over 70,000 asylum seekers have been sent back to wait in Mexico (Transactional Records Access Clearinghouse 2021).

When the policy was announced, former Secretary of Homeland Security, Kirstjen Nielsen, touted the MPP program as "an unprecedented action that will address the urgent humanitarian and security crisis at the Southern border" (DHS 2019g). However, in the years since its implementation, the program has resulted in serious harm to asylum seekers and placed children and families in perilous conditions. The MPP program exacerbates preexisting issues in US immigration courts including a lack of access to counsel and barriers to legal representation, lack of transparency in immigration proceedings, and limited legal protections for asylum seekers (Eagly and Shafer 2016; Ardalan 2015; Transactional Records Access Clearinghouse 2019d; Innovation Lab and Southern Poverty Law Center 2019).

The MPP policy became a fundamental part of the Trump Administration's immigration principles and policies - several of which represented affronts to asylum in contradiction of longstanding US and international refugee laws (Human Rights Watch 2017). These deterrencefocused policies include but are not limited to family separation, narrowed eligibility grounds for asylum, "metering," safe third country agreements, and a proposed fee for applying for asylum (Aguilera 2019; McCullough and Aguilar 2018; Trovall 2019; Narea 2019; Kanno-Youngs and Jordan 2019). The MPP returns asylum seekers to danger in Mexico and creates significant barriers to due process that undermine their rights. The Biden Administration should immediately end the program and prohibit the use of government funds to continue the MPP program. They should instead redirect these funds to the US immigration court system to ensure fair and timely procedures. The following sections are organized as "Questions \& Answers" to address key concerns regarding the MPP program and immigration courts in the United States.

\section{WHAT IS THE MPP PROGRAM?}

The Trump Administration's Migrant Protection Protocols program is an asylum policy action administered by the United States Department of Homeland Security. The program requires that certain asylum seekers who attempt to enter the United States at the US-Mexico border wait in Mexico for the duration of their US immigration court procedures. The length of the asylum process in the US varies, taking between six months and several years (National Immigration Forum 2019). 
DHS justified the policy arguing that previous laws and court decisions made it easier for asylum seekers to enter the country illegally and that the US immigration system enables smugglers and traffickers. DHS also cited a dramatic increase in illegal immigration and fraudulent claims of asylum. Further, in October 2020, Acting Secretary Chad Wolf said that the MPP policy "helps promote a safer and more orderly process along the Southwest border, discourages individuals from making meritless asylum claims, and enables quick immigration results" (DHS 2020). Proponents of the policy emphasize border security and assert that the MPP program is in place to avert human smuggling and trafficking.

However, immigration advocates like Yael Schacher at Refugees International argue that the MPP program conflicts with longstanding obligations to US and international refugee law (2019). In 1968, the US committed to the central guarantees of the 1951 Convention Relating to the Status of Refugees (the Refugee Convention) and acceded to the Refugee Convention's 1967 protocol. In 1980, the US Congress passed the Refugee Act, bringing the US in compliance with the Refugee Convention protocol, incorporating the convention's definition of refugee into US law, and adopting the principle of non-refoulement. The principle of non-refoulement prohibits the return of refugees to countries where they would face persecution. Despite this, DHS states that the legal basis for the MPP program is Section 235(b)(2)(C) of the Immigration and Nationality Act (INA), which "authorizes the DHS to return certain applicants for admission to the contiguous country from which they are arriving on land (whether or not at a designated port of entry), pending removal proceedings under INA § 240" (DHS 2019d). This legal interpretation is the subject of ongoing litigation.

In April 2019, US District Judge Richard Seeborg in San Francisco issued a preliminary injunction that blocked the program (Washington Post 2019). But, in May 2019, the US Court of Appeals for the Ninth Circuit in San Francisco issued a stay of proceedings that allowed the government to continue to send asylum seekers to Mexico while the appeal of the preliminary injunction is considered. In December 2019, the legality of MPP was challenged in litigation led by the American Civil Liberties Union and other immigrants' rights organizations (Blitzer 2019). The Supreme Court was set to hear oral arguments on March 1, 2021 but granted a request from the Biden Administration to remove the hearing from the calendar in light of immigration directives issued by the new administration (Quinn 2021). The legality of the program has also faced opposition internally. Individual asylum officers and the labor union that represents federal asylum officers have condemned the program as illegal and in violation of the Immigration and Nationality Act (Sargent 2019; Allyn 2019).

\section{WHO IS BEING PLACED IN THE MPP PROGRAM?}

Children, families, and individuals seeking asylum in the United States are being placed in the MPP program (Cooke, Rosenberg, and Levinson 2019a; Silva 2019; Levinson, Rosenberg, and Cooke 2019b). To date, over 70,000 asylum seekers have been returned to Mexico through the program (TRAC 2021). A Human Rights Watch analysis found that at least 13 pregnant women were placed in the program and 10 asylum seekers had disabilities or chronic conditions, facing obstacles to accessing basic services while they waited in Mexico (Human Rights Watch 2019b). Though "individuals from vulnerable populations may be excluded on a case-by-case basis" according to the DHS (DHS 2019g), in practice, these exemptions have been inconsistent; 
advocates and lawyers have found persons with mental health conditions and members of the LGBTQ community returned back to Mexico (Rose 2019). By definition, asylum seekers fleeing violence and persecution in their home countries are populations of people subject to heightened vulnerabilities.

Given recent migration patterns, the MPP program has returned mostly Central American families to wait in Mexico. Persons of other nationalities, including African, Cuban, and Venezuelan asylum seekers, have also become ensnared in the program (Brown 2019; Sheridan 2019; Galvan 2019). As of March 2021, the US government has not made comprehensive demographic data on who has been returned to Mexico through the program publicly available. However, the Transactional Records Access Clearinghouse (TRAC) at Syracuse University obtained data on the MPP program from the US government using the Freedom of Information Act (FOIA) (TRAC 2021). Using the data, TRAC published the nationality of people placed in the MPP program. Out of 71,021 MPP proceedings through February 2021, the top five nationalities of people returned to Mexico are Honduran (23,051 or roughly 32 percent), Guatemalan (15,802 or roughly 22 percent), Cuban (11,478 or roughly 16 percent), El Salvadorian $(8,120$ or roughly 11 percent), and Ecuadorian (5,944 or roughly 8 percent).

\section{WHERE IS THE MPP PROGRAM IN PLACE?}

The MPP program began as a pilot at the San Ysidro port of entry near San Diego, California and Tijuana, Mexico. In a memorandum and policy guidance issued with an effective date of January 28, 2019, Secretary Nielsen launched the Migrant Protection Protocols as what was initially meant to serve as an experimental program (United States Citizenship and Immigration Services 2019; Customs and Border Protection 2019). According to The Washington Post, the first asylum seeker returned to Mexico was a Honduran man named Carlos Gomez Perdomo, who was sent back to Tijuana, Mexico on January 29, 2019 (Averbuch and Sieff 2019).

By March 2019, the MPP program expanded to Calexico, California and El Paso, Texas (Rose 2019; Montes 2019). This initial expansion occurred despite concerns raised that border officers were not adhering to policy guidelines at the San Ysidro port of entry (Schacher 2019). Between the implementation of the pilot phase and the program's expansion in March, DHS did not publicly release any program evaluation or assessment on the MPP policy. Speaking anonymously to the press, asylum officers indicated that there were issues around training for the new standards set by the program during the pilot phase (Lind 2019).

On June 7, 2019, the Trump Administration announced that it would "immediately expand the implementation" across the entire US-Mexico border (Department of State 2019a). In July 2019, the administration expanded MPP to Laredo and Brownsville, Texas (Roldan 2019; Root 2019). In an October 28, 2019 press release, the DHS announced the program's expansion to Eagle Pass, Texas (DHS 2019f). In late November and early December 2019, the Migrant Protection Protocols was expanded to Tucson and Nogales, Arizona (Prendergast 2019).

The rapid expansion of the MPP program occurred amid an internal review of the program ordered by then-Acting DHS Secretary Kevin McAleenan. Produced by senior DHS officials, the 
review found that the program exacerbated tensions between US Customs and Border Protection (CBP), the agency responsible for patrolling the border, and US Citizenship and Immigration Services (USCIS), the agency responsible for interviewing asylum seekers to assess credible fears (Aleaziz 2019a). The review found CBP officials prevented asylum seekers' access to USCIS officials and pressured USCIS asylum officers to deny asylum seekers' persecution claims. Members of Congress have requested that the DHS provide them with the report and recommendations from the review (Aleaziz 2019b; Senator Leahy 2019).

\section{WHAT ARE IMMIGRATION COURTS AND WHAT ARE THE ISSUES WITH THEM?}

Immigration courts uphold the immigration laws of the United States and oversee decisions in applications for asylum and citizenship. Immigration courts fall under the jurisdiction of the US Department of Justice (DOJ) and are specifically administered by the Executive Office of Immigration Review (EOIR) (DOJ EOIR 2018). Housed within the DOJ, the EOIR was created on January 9, 1983 to be independent from what was then the Immigration and Naturalization Service (INS), which is now part of the DHS.

The stated mission of EOIR is "to adjudicate immigration cases in a careful and timely manner, including cases involving detained aliens, criminal aliens, and aliens seeking asylum as a form of relief from removal, while ensuring the standards of due process and fair treatment for all parties involved" (DOJ EOIR 2019a). The agency is made up of over 2,000 employees across 68 immigration courts and adjudication centers (DOJ EOIR 2019b). According to an October 2019 DOJ report, the EOIR has a total of 442 immigration judges on staff (DOJ EOIR 2019e).

There are several critical issues facing United States immigration courts. Courts are underfunded and under-resourced, resulting in individual judges with exceedingly large caseloads. Immigrants often go unrepresented, drastically affecting the outcomes of their cases. Additionally, the EOIR has been accused of a lack of transparency in its data collection and sharing.

Over the last two decades, the US immigration system has prioritized spending on enforcement and detention over ensuring courts are well-resourced. According to one analysis of spending in the US immigration system, CBP and Immigration and Customs Enforcement (ICE) combined spending increased 105 percent from \$9.1 billion in Fiscal Year (FY) 2003 to approximately \$18.7 billion in FY 2015 (American Immigration Council 2019). Immigration court spending increased by a much smaller magnitude over the same time period-only 74 percent, from $\$ 199$ million to $\$ 347.2$ million. The disproportionate funding levels contributes to a growing backlog of cases. Though the EOIR hired an additional 92 immigration judges in FY 2019resulting in a net increase of 47 judges after accounting for resignations and retirements-each judge in the immigration court system still has an active pending caseload of over 2,000 cases (Transactional Records Access Clearinghouse 2019c).

Legal representation is another issue in the US immigration court system that has significant consequences for asylum seekers and the administration of the courts. According to the American Immigration Council, between 2007 and 2012, only 37 percent of all immigrants secured legal representation in their removal cases (2019). A study by Sabrineh Ardalan, Director of the 
Harvard Law School Immigration and Refugee Clinic, found that financial, language, and cultural barriers prevented immigrants from obtaining counsel (2015). While asylum seekers in US immigration courts have a right to counsel, the US government does not provide governmentappointed counsel like they do for defendants in criminal cases. As such, obtaining representation poses financial challenges for poor immigrants. A 2019 report by the Migration Policy Institute highlighted the impact of legal representation in immigration proceedings, showing a positive correlation between representation rates and asylum grant rates. The report also revealed that for proceedings between 2008 and June 2019, 97 percent of immigrants with an attorney appeared, compared to 83 percent of the total (Esthimer 2019).

Transparency within the US immigration court system is also a concern. During the Trump Administration, the EOIR was charged with inconsistent data collection and for sharing inaccurate data. In an October 2019 report, TRAC found that EOIR was "silently deleting swaths of records in their entirety from the data releases" (TRAC 2019a). Lack of transparency in data compiled by EOIR was coupled with a non-transparent appointment process for immigration judges and insufficient mechanisms to hold judges accountable for misconduct (Southern Poverty Law Center and the Innovation Law Lab 2019).

\section{HOW LONG IS THE BACKLOG OF CASES IN US IMMIGRATION COURTS?}

According to the EOIR "Statistics Yearbook," in September 2018, the total pending caseload was 789,258 cases - a 20 percent increase from FY 2017 (DOJ EOIR 2018; DOJ EOIR 2017). As of October 2019, there were an additional 987,274 pending cases. However, as TRAC points out, the current backlog of cases in US immigration courts has certainly surpassed over one million pending cases, as EOIR's figures do not include cases that have yet to be calendared (TRAC 2018). As TRAC reports, "When the 322,535 cases that remain to be calendared are added, the current backlog climbs from 542,411 at the start of the Trump Administration to 1,346,302 cases today a whopping 148 percent increase" (TRAC 2019c).

The backlog in the immigration court system causes asylum seekers to wait anywhere from six months to several years to have decisions made in their cases (National Immigration Forum 2019). The average length of time that immigrants wait for hearings varies across court locations. In New York City, for example, the average time immigrants wait for a court hearing is 1,328 days - over three and a half years (TRAC 2019c). The backlog places a burden on both those seeking to obtain justice through the courts as well as the court's administrators. When factoring in un-calendared cases, TRAC finds that the average caseload for immigration judges is over 3,000 cases. As TRAC notes, "even if caseloads were frozen and the Immigration Court stopped accepting any new cases, it would still take the existing pool of immigration judges an estimated 4.4 years to work through this accumulated backlog" (TRAC 2019c). The increase in the backlog since the start of the Trump Administration can largely be attributed to an administration policy decision to reopen hundreds of thousands of cases that were previously pushed off the court's docket (Aleaziz 2018). 
MPP proceedings added to the backlog and do not absolve immigration judges of cases already on their docket. While the US government has shifted judges to take on more MPP cases, they still have non-MPP cases to handle. Some immigration judges in San Diego were reported to have up to 50 MPP cases scheduled each day, forcing them to push back some of their other cases (Srikrishnan 2019).

\section{HOW DOES THE MPP PROGRAM EXACERBATE PREEXISTING ISSUES IN US IMMIGRATION COURTS?}

Many of the issues with the MPP program mirror and exacerbate preexisting issues in US immigration courts. The chaos and confusion following the policy's implementation led one US immigration official to tell Reuters that the MPP program had effectively "broken the courts" (Cooke, Rosenberg, and Levinson 2019c). According to the American Bar Association (ABA), lawyers in the US have difficulties contacting clients in Mexico due to the need to cross country borders and the uncertain living conditions for asylum seekers in Mexican cities. The ABA states "for MPP asylum seekers, it is nearly impossible to exercise this [statutory] right [to counsel] from Mexico" (American Bar Association 2019); thus, asylum seekers in the program are woefully underrepresented. As of February 2021, roughly 92 percent of the 71,021 MPP cases went unrepresented (TRAC 2021). In one report, TRAC noted that "as of the end of June 2019, a total of 1,155 MPP cases had already been decided. Yet only 14 of these-just 1.2 percent-were represented" (Transactional Records Access Clearinghouse 2019d).

While immigration courts in the US provide a Legal Orientation Program (LOP) in partnership with the Vera Institute of Justice, in June 2019, the El Paso immigration courthouse ended a "friend of the court" program that aided asylum seekers in the MPP program (Aguilar 2019). An immigration attorney in El Paso told the Texas Tribune she was informed by court personnel that the friend of the court program was discontinued because of ongoing litigation surrounding the MPP program.

The US government has also had issues with its MPP data. CBP had to revise a November 2019 figure of 59,000 asylum seekers placed in the program to 54,000 in December 2019 after an agency audit found that some people seeking protection had been counted twice.

\section{WHAT ARE TENT COURTS?}

Some immigration proceedings are being conducted in "tent courts" - tents erected along the US-Mexico border for court hearings. Under the MPP program, DHS opened tent courts at the border in Laredo and Brownsville, Texas on September 11 and 12, 2019 with plans to open an additional facility in Yuma, Arizona (Fernandez, Jordan, and Dickerson 2019). Even prior to the coronavirus pandemic, proceedings in tent courts were held via video conference, many of which were with judges in a different state hundreds of miles away. Advocates argue these video conference proceedings do not allow for fair hearings or meaningful participation (Sang 2019). The US Government Accountability Office (GAO) has raised concerns about technical and 
translation issues with video-teleconferencing (VTC) for immigration procedures and found that the immigration court system does not use VTC in accordance with best practices (Government Accountability Office 2018).

Tent courts used for MPP proceedings have been closed off from the public and the media. Members of Congress condemned these tent courts as "shrouded in secrecy" in a letter to former DHS Secretary Chad Wolf, arguing that little information was provided to the public or to Congress about their opening, and that the implementation of tent courts did not undergo a stringent review process (Ortiz 2019). Ashley Tabaddor, President of the National Association of Immigration Judges, told the Texas Observer that because tent courts are closed off to legal observers and the media, they do not allow for accountability to the public:

"Normal immigration court is open to the public. In civil proceedings in America, one of the fundamental tenets of our judicial system is that there has to be accountability to the public. We don't do stuff behind closed doors. That is not what America is about. And yet, with each [immigration] policy decision in the last three years, we are moving closer and closer to a model that doesn't resemble anything in the American judicial system; it's more like what you might see, perhaps, in China or Russia, countries that we hear asylum cases from, where judicial decisions are being made by prosecutors or at the direction or influence of prosecutors in the guise of a court" (Bova 2019).

\section{ARE IMMIGRANTS ABUSING "LOOPHOLES" IN ASYLUM LAWS?}

The Trump Administration and its officials repeatedly made the claim that asylum seekers are abusing "loopholes" in immigration laws. For example, when DHS introduced the MPP policy, they claimed that most asylum cases from the Northern Triangle (El Salvador, Guatemala, and Honduras) are fraudulent, citing a statistic that "approximately 9 out of 10 asylum claims from Northern Triangle countries are ultimately found non-meritorious by federal immigration judges" (DHS 2019g). In a declaration submitted in Innovation Law Lab v. Nielsen, immigration lawyer Aaron Reichlin Melnick disputed this claim, saying, "asylum seekers from Northern Triangle countries win asylum or are granted an alternative form of relief at rates more than double what DHS claims...statistics produced by EOIR show that in FY 2018 over 25 percent of Northern Triangle nationals were granted asylum or otherwise permitted to remain in the United States" (ACLU 2019).

To the contrary, what the Trump Administration labeled as "loopholes" are in fact longstanding protections for the rights of immigrants. These alleged "loopholes," such as the Trafficking Victims Protection Reauthorization Act (TVPRA) and the Flores settlement agreement, are safeguards against injustice and abuse. The TVPRA provides legal safeguards to unaccompanied migrant children that are grounded in international human rights law (Kids in Need of Defense 2019). The Flores settlement agreement similarly sets standards and limits on the length of time which children can be held in immigration detention (Margulies 2019).

Claims that asylum seekers do not show up for court are similarly unfounded. In November 2018, President Trump falsely claimed that only three percent of asylum seekers make their court 
appearances (C-SPAN 2018). The EOIR's own data reflects that most migrants show up for their court dates; using EOIR data, the American Immigration Council found the appearance rate of all immigrants placed in removal proceedings from FY 2008 to June 2019 to be 83 percent with a 97 percent appearance rate if immigrants were represented by an attorney (American Immigration Council 2019). In separate studies, both the American Immigration Council and TRAC found that the majority of families released from detention attended all their immigration court hearings (Eagly, Shafer, and Whalley 2018; TRAC 2019).

\section{IS THE MPP PROGRAM THE SAME AS "METERING"?}

The MPP program is distinct from the Trump Administration's policy of "metering," but is similarly used as a means to deter asylum seekers from claiming asylum (Laird 2019). Metering is a border management policy by which ports of entry only process a certain number of individuals each day. Metering has caused asylum seekers or shelter staff to create waiting lists on their own volition and initiative (Driver 2019). Persons managing these waiting lists are often not US or Mexican government officials - rather, they are commonly the asylum seekers themselves.

Revealed in an article from The New York Times, metering has allowed on average only 34 people to cross the border at one specific port of entry each day, leading to waiting times at ports of entry to be in the range of six to nine months (Kao and Lu 2019). When combined together, metering and the MPP program have made applying for asylum at the US border increasingly difficult and risky for asylum seekers. Metering came under intense scrutiny following the deaths of asylum seeker and father, Óscar Alberto Martínez Ramírez, and his 23-month-old daughter, Valeria, in June 2019. According to the Mexican newspaper La Jornada, the father and daughter were denied entry by CBP officers and were subsequently made to wait on a metering waitlist (Le Duc 2019). Óscar and Valeria's deaths were depicted in a shocking photo showing the two of them lying face down on the edge of the Rio Grande after they drowned together. The photo of Óscar and Valeria's bodies shed light on the dangerous journey Central American asylum seekers face as they try to seek refuge in the United States (Hjelmgaard 2019).

Stories such as this have led some to argue that these policies actually may directly encourage more dangerous border crossings between ports of entry or discourage asylum seekers from seeking refuge in the US altogether (Kanno-Youngs 2019; Horton 2018) — an outcome in line with the anti-immigration stance of the Trump Administration.

\section{WHAT ARE SOME OF THE RISKS ASYLUM SEEKERS FACE WHILE WAITING IN MEXICO?}

Many of the cities that asylum seekers are forced to wait in while in Mexico are dangerous, with high risks of kidnapping, extortion, and violence. Some of these cities have recently been or are currently subject to travel advisories by the Department of State. As of December 2019, the US Department of State had a "Do Not Travel" warning to the Mexican state of Tamaulipas (Department of State 2019b), but the Mexican cities of Matamoros, Nuevo Laredo, and Reynosa-all cities that people have been returned to under the Migrant Protection Protocols - are in the 
state of Tamaulipas. According to a report specifically focused on the state of Tamaulipas, "between June 2018 and July 2019, 45 percent of the 2,315 people (either migrants, asylum seekers, refugees, or returnees) treated by [Médicins San Frontières] mental health teams in Reynosa and Matamoros reported being victims of violence during their journey through Mexico" (Doctors Without Borders 2019).

Human Rights First has documented "at least 1,544 publicly reported cases of kidnapping, rape, torture, assault, and other violent attacks against asylum seekers and migrants returned to Mexico" (2021). Another study by the US Immigration Policy Center at the University of California, San Diego surveyed 607 asylum seekers in the MPP program and found that over half of respondents who reported being threatened with physical violence while waiting in Mexico did in fact later experience violence, including beatings, robbery, and extortion (Wong 2019). The study found that the longer respondents waited in Mexico, the more likely they were to be threatened with physical violence before they made it to their court date. Upon release of the study, the lead author and founding director of the US Immigration Policy Center, Tom K. Wong, said "the Remain in Mexico policy has begged important questions about whether there are sufficient safeguards in place to ensure that the lives and freedom of asylum seekers are not threatened. The data show that there are not sufficient safeguards-lives are literally being put at risk" (Kiderra 2019).

Additionally, shelters have become overwhelmed, making living situations uncertain (Montoya-Galvez 2019). According to Human Rights Watch, the Mexican government noted in July 2019 that "the number of asylum seekers marooned in Ciudad Juarez already outnumbered the spaces available in free humanitarian shelters by 11 to 1" (Human Rights Watch 2019a). Activists, advocates, and journalists have documented deplorable conditions for asylum seekers waiting in Mexico (Washington Post Editorial Board 2019). Due to the lack of shelter space, many asylum seekers face homelessness while they wait and have been forced to live in makeshift camps with substandard sanitary conditions-with over 1,500 asylum seekers living in these tent encampments near the Gateway International Bridge in Matamoros, Tamaulipas at one point in 2019 (Leanos Jr. 2019). Asylum seekers with disabilities have also faced issues accessing basic needs. Neither the encampments nor many of the border shelters meet accessibility standards for persons with disabilities. Further, living conditions in these encampments have led to the spread of illnesses. Because CBP requires clear medical screenings before allowing migrants to pursue their claims, some asylum seekers who fell sick in the camps were then returned to Mexico with their court dates rescheduled (Hennessy-Fiske 2019).

In addition to lack of shelter space, finding work in Mexico has proved to be challenging. Though a provision in the US government's agreement with Mexico stated asylum seekers would be accommodated with work permits to find jobs, work has been hard to come by given the temporary and precarious nature of asylum seekers' wait in Mexico. Notably, African asylum seekers stuck in Mexico have said they cannot find work and have been subjected to racism (Kahn 2019).

WHAT ARE THE COSTS ASSOCIATED WITH THE MPP PROGRAM? 
The MPP program has cost the United States upwards of $\$ 10$ billion dollars as part of its informal deal with Mexico (Stevenson 2018). Specifically, one assessment noted that "DHS erected temporary, dedicated MPP hearing locations... at a total six-month construction and operation cost of approximately $\$ 70$ million" (DHS 2019c). The MPP program is also funding the busing of asylum seekers to and from court hearings (Blitzer 2019). In addition to high monetary costs, the policy has resulted in immeasurable human costs.

As discussed in detail above, asylum seekers face significant challenges as they attempt to seek refuge in the United States. Many already wrestle with traumatic experiences as they flee their countries, and the MPP program subjects asylum seekers to re-traumatization (Heffron 2019; CBS News 2019). The non-governmental organization Physicians for Human Rights found multiple cases of asylum seekers exposed to MPP who showed symptoms of Post-Traumatic Stress Disorder (PTSD) (Nelson and Habbach 2019). The Trump Administration's legacy of antiimmigrant asylum policies is not only currently costing taxpayers hundreds of millions of dollars, but the human toll of these policies will also need to be reckoned with for decades to come.

\section{CONCLUSION: WHAT SHOULD THE US GOVERNMENT DO AS AN ALTERNATIVE TO THE MPP PROGRAM?}

As the MPP program has expanded, so too have affronts and abuses to asylum seekers. The MPP program does not fix nor address the crisis at the Southern border in a humane manner. On the contrary, it worsens the humanitarian crisis at the border and exacerbates preexisting issues in the US immigration court system. The US government should defund and end the MPP program; instead, the government should protect the rights of asylum seekers and uphold its longstanding obligations to US and international laws on the rights of refugees.

The Biden Administration should prioritize ending MPP—because DHS instituted the policy unilaterally (without support from Congress nor notice-and-comment rulemaking), it can unilaterally revoke it. There are also several short-, medium-, and long-term actions that the US government can take to convert the program to reflect a more humane approach to immigration policy.

First, the US Congress should continue to expose the program's abuses through robust investigatory congressional hearings and by sending delegates to border shelters, tent courts, and ports of entry. The US government already has made some progress on this front. On November 19, 2019, the House Homeland Security Committee hosted a hearing entitled, "Examining the Human Rights and Legal Implications Of DHS' 'Remain in Mexico' Policy" (House Committee on Homeland Security 2019). At the hearing, Michael Knowles, head of the USCIS asylum officer union, testified that asylum officers told him adjudicating cases under this program has left them "feeling like they are complicit in human rights abuses" (Misra 2019). On November 19, 2019, Senator Dianne Feinstein wrote a letter calling upon Senator Lindsey Graham to hold a hearing on MPP in the Senate Judiciary Committee, which would allow for additional oversight over the program (Senator Feinstein 2019). Oregon Senator, Jeff Merkley, released a report on the Trump Administration's "gutting of the legal asylum system" that called for further investigation of MPP (Senator Merkley 2019). 
Second, Congress should consider signing into legislation the Asylum Seeker Protection Act introduced by Representative Veronica Escobar on May 10, 2019 (Representative Escobar 2019). The bill would prohibit any funds to be used to enforce MPP and would effectively defund the program.

Finally, the United States government should redirect funding from the immigration enforcement and detention system toward the immigration court system. Underfunded immigration courts undermine the rights of asylum seekers and refugees. Further, as discussed above, the Trump Administration exposed how executive branch interference can exploit the processes of the courts (American Immigration Lawyers Association 2020a; Miroff 2018; American Immigration Lawyers Association 2020b). To protect the rights of asylum seekers and other immigrants seeking justice, the US should ensure the efficiency of equitable immigration procedures by ensuring that courts are free from influence by the executive branch. 


\section{REFERENCES}

Aguilar, Julian and Jolie McCullough. 2018. "There are new, tougher guidelines for migrants seeking asylum in the United States." Texas Tribune, July 12, 2018.

https://www.texastribune.org/2018/07/12/migrants-asylum-tougher-guidelines/.

Aguilar, Julian. 2019. "In El Paso court, migrants no longer get legal advocates or pre-hearing briefings on their rights." Texas Tribune, July 11, 2019.

https://www.texastribune.org/2019/07/11/el-pasos-backlogged-immigration-court-haltsassistance-asylum-seekers/.

Aguilera, Jasmine. 2019. "Here's What to Know About the Status of Family Separation at the U.S. Border, Which Isn't Nearly Over.” Time, October 25, 2019. https://time.com/5678313/trump-administration-family-separation-lawsuits/.

Aleaziz, Hamed. 2019a. "US Border Officials Pressured Asylum Officers To Deny Entry To Immigrants Seeking Protection, A Report Finds." BuzzFeed News, November 15, 2019. https:/www.buzzfeednews.com/article/hamedaleaziz/dhs-asylum-report-mppimmigration-remain-mexico.

Aleaziz, Hamed. 2019b. "Senators And Presidential Candidates Are Demanding The DHS Report On A Controversial Asylum Policy.” BuzzFeed News, November 19, 2019. https://www.buzzfeednews.com/article/hamedaleaziz/senators-and-presidentialcandidates-demand-dhs-report-on.

Aleaziz, Hamed. 2018. "The Trump Administration Is Seeking To Restart Thousands Of Closed Deportation Cases." BuzzFeed News, August 15, 2018. https://www.buzzfeednews.com/article/hamedaleaziz/trump-deportations-immigrationice-dhs-courts.

Allyn, Bobby. 2019. “Asylum Officers: Trump's 'Remain In Mexico' Policy Is Against 'Moral Fabric' Of U.S.” NPR, June 27, 2019. https://www.npr.org/2019/06/27/736461700/asylum-officers-trumps-remain-in-mexicopolicy-is-against-moral-fabric-of-u-s.

American Bar Association. 2019. Statement of Laura Pena. Chicago, IL: American Bar Association. https://homeland.house.gov/imo/media/doc/Testimony-Pena.pdf.

American Immigration Council. 2019. "Immigrants and Families Appear in Court: Setting the Record Straight.” Washington, DC: American Immigration Council. https://www.americanimmigrationcouncil.org/research/immigrants-and-families-appearcourt.

American Immigration Council. 2019. "Empty Benches: Underfunding of Immigration Courts Undermines Justice.” Washington, DC: American Immigration Council. https://www.americanimmigrationcouncil.org/research/empty-benches-underfundingimmigration-courts-undermines-justice.

American Immigration Lawyers Association. 2019. "AILA Joins Organizations and Academics to Call for End to Remain in Mexico Program." Washington, DC: American Immigration 
Lawyers Association. https://www.aila.org/advo-media/aila-correspondence/2019/callfor-end-to-remain-in-mexico-program.

American Immigration Lawyers Association. 2020a. "Featured Issue: Immigration Courts." Washington, DC: American Immigration Lawyers Association. https://www.aila.org/advo-media/issues/all/immigration-courts.

American Immigration Lawyers Association. 2020b. "Featured Issue: DOJ Moves to Decertify the Immigration Judges Union." Washington, DC: American Immigration Lawyers Association. https://www.aila.org/advo-media/issues/all/doj-move-decertify-immigrationjudge-union.

Ardalan, Sabrineh. 2015. "Access to Justice for Asylum Seekers: Developing an Effective Model of Holistic Asylum Representation." University of Michigan Law Review 48, no. 4. 10011038. https://repository.law.umich.edu/cgi/viewcontent.cgi?article=1141\&context=mjlr

Averbuch, Maya and Kevin Sieff. 2019. "Asylum seeker is sent back to Mexico as Trump administration rolls out new policy." Washington Post, January 29, 2019. https://www.washingtonpost.com/world/the_americas/asylum-seekers-are-being-sentback-to-mexico-as-trump-administration-rolls-out-new-policy/2019/01/29/a0a89e9c233b-11e9-b5b4-1d18dfb7b084_story.html.

Blitzer, Jonathan. 2019. "How the U.S. Asylum System Is Keeping Migrants at Risk in Mexico." New Yorker, October 1, 2019. https://www.newyorker.com/news/dispatch/how-the-usasylum-system-is-keeping-migrants-at-risk-in-mexico.

Bova, Gus. 2019. "Immigration Judge Slams 'Remain in Mexico' Tent Courts.” Texas Observer, September 24, 2019. https://www.texasobserver.org/tent-courts-ashley-tabaddor-borderlaredo-asylum-immigration/.

Brown, Marcia. 2019. "African Asylum Seekers to the U.S. Stuck on the Mexico-Guatemala Border." The American Prospect, September 12, 2019. https://prospect.org/power/african-asylum-seekers-u.s.-stuck-mexico-guatemala-border/.

Caldwell, Alicia A., Alejandro Lazo, and Juan Montes. 2019. "In a Reversal, Fewer Migrants Are Arrested at the Border." Wall Street Journal, December 10, 2019. https://www.wsj.com/articles/in-reversal-of-spring-crisis-border-arrests-drop-for-sixthstraight-month-11575912090.

CBS News. 2019. "Doctors risk lives tackling Trump policy sending migrants back to Mexico: "I've seen people kidnapped twice".” October 12, 2019. https://www.cbsnews.com/video/doctors-risk-lives-tackling-trump-policy-sendingmigrants-back-to-mexico/.

Cooke, Kristina, Mica Rosenberg, and Reade Levinson. 2019a. "Exclusive: U.S. migrant policy sends thousands of children, including babies, back to Mexico." Reuters, October 11, 2019. https://www.reuters.com/article/us-usa-immigration-babies-exclusive/exclusive-us-migrant-policy-sends-thousands-of-children-including-babies-back-to-mexicoidUSKBN1WQ1H1. 
Cooke, Kristina, Mica Rosenberg, and Reade Levinson. 2019b. "Exclusive: Asylum seekers returned to Mexico rarely win bids to wait in U.S." Reuters, June 12, 2019.

https://www.reuters.com/article/us-usa-immigration-returns-exclusive/exclusive-asylumseekers-returned-to-mexico-rarely-win-bids-to-wait-in-u-s-idUSKCN1TD13Z.

Cooke, Kristina, Mica Rosenberg, and Reade Levinson. 2019c. "Hasty rollout of Trump immigration policy has 'broken' border courts." Reuters, September 10, 2019. https://www.reuters.com/article/us-usa-immigration-courts-insight/hasty-rollout-oftrump-immigration-policy-has-broken-border-courts-idUSKCN1VV115.

Cornell Law School Legal Information Institute. 2019. "8 U.S. Code § 1158.Asylum.” Accessed March, 23, 2021. https://www.law.cornell.edu/uscode/text/8/1158.

C-SPAN. 2018. "President Trump Remarks on Immigration.” Accessed March, 23, 2021. https://www.c-span.org/video/?460812-1/president-trump-unveils-immigration-policyproposal.

Department of Homeland Security (DHS). 2019a. "Policy Guidance for Implementation of the Migrant Protection Protocols." Washington, DC: United States Department of Homeland Security. https://www.dhs.gov/publication/policy-guidance-implementation-migrantprotection-protocols.

DHS. 2019b. "Migrant Protection Protocols." Washington, DC: United States DHS. https://www.dhs.gov/migrant-protection-protocols.

DHS. 2019c. “Assessment of the Migrant Protection Protocols (MPP).” Washington, DC: United States DHS.

https://www.dhs.gov/sites/default/files/publications/assessment of the migrant protecti on protocols mpp.pdf.

DHS. 2019d. "Guidance for Implementing Section 235(b)(2)(C) of the Immigration and Nationality Act and the Migrant Protection Protocols." Washington, DC: United States DHS. https://www.uscis.gov/sites/default/files/document/memos/2019-01-28-Guidancefor-Implementing-Section-35-b-2-C-INA.pdf.

DHS. 2019e. "Guidance on Migrant Protection Protocols." Washington, DC: United States DHS. https://www.uscis.gov/sites/default/files/document/memos/2019-01-28-Guidance-forImplementing-Section-35-b-2-C-INA.pdf.

DHS. 2019f. "DHS Expands MPP Operations to Eagle Pass.” Washington, DC: United States DHS. https://www.dhs.gov/news/2019/10/28/dhs-expands-mpp-operations-eagle-pass.

DHS. 2019g. "Migrant Protection Protocols.” Washington, DC: United States DHS. https://www.dhs.gov/news/2019/01/24/migrant-protection-protocols.

DHS. 2020. "Remarks as Prepared by Acting Secretary Chad F. Wolf Highlighting Border Security and Immigration Policies of the Trump Administration." Washington, DC: United States DHS. https:/www.dhs.gov/news/2020/10/22/remarks-prepared-actingsecretary-chad-f-wolf-highlighting-border-security-and.

Doctors Without Borders/Médecins Sans Frontières. 2019. "US 'Remain in Mexico' policy endangers lives of asylum seekers in Tamaulipas state.” New York, NY: Doctors Without 
Borders. https://www.msf.org/us-migration-policy-endangers-lives-asylum-seekerstamaulipas-state-mexico.

Driver, Alice. 2019. "Life on the U.S. asylum waitlist: a long and dangerous wait." National Geographic, September 25, 2019.

https://www.nationalgeographic.com/culture/2019/09/life-united-states-asylum-waitlistlong-dangerous/.

Eagly, Ingrid and Steven Shafer. 2016. "Access to Counsel in Immigration Court." Washington, DC: American Immigration Council.

https://www.americanimmigrationcouncil.org/research/access-counsel-immigrationcourt.

Eagly, Ingrid, Steven Shafer, and Jana Whalley. 2018. "Detaining Families: A Study of Asylum Adjudication in Family Detention." Washington, DC: American Immigration Council. https://www.americanimmigrationcouncil.org/research/detaining-families-a-study-ofasylum-adjudication-in-family-detention.

Editorial Board. 2019. "A Trump policy has subjected asylum seekers to appalling conditions." Washington Post, August 13, 2019. https://www.washingtonpost.com/opinions/a-trumppolicy-has-subjected-asylum-seekers-to-appalling-conditions/2019/08/13/9eb6cc5a-b7c711e9-bad6-609f75bfd97f_story.html.

Escobar, Representative Veronica. 2019. "Congresswoman Veronica Escobar Introduces Legislation to Defund Dangerous 'Remain in Mexico' Policy.” Accessed March 23, 2021. https://escobar.house.gov/news/documentsingle.aspx?DocumentID=207.

Esthimer, Marissa. 2019. "Crisis in the Courts: Is the Backlogged U.S. Immigration Court System at Its Breaking Point?" Washington, DC: Migration Policy Institute. https://www.migrationpolicy.org/article/backlogged-us-immigration-courts-breakingpoint\#: : text=Migration\%20Information\%20Source,Crisis\%20in\%20the \%20Courts\%3A\%20Is\%20the\%20Backlogged\%20U.S.\%20Immigra tion,System $\% 20$ at $\% 20 I t s \% 20$ Breaking $\% 20$ Point $\% 3$ F \& text $=I \mathrm{t} \% 20$ examines $\% 20$ the $\% 20$ o verall $\% 20$ backlog,by $\% 20$ court $\% 20$ and $\% 20$ representation $\% 20$ status.

Feinstein, Senator Dianne. 2019. "Letter to Senator Lindsey Graham.” Accessed March 23, 2021. https://www.feinstein.senate.gov/public/index.cfm/press-releases?id=ABBBE325E3AB-4732-AC90-8F22B47291ED.

Fernandez, Manny, Miriam Jordan, and Caitlin Dickerson. 2019. "The Trump Administration's Latest Experiment on the Border: Tent Courts.” New York Times, September 12, 2019. https://www.nytimes.com/2019/09/12/us/border-tent-courts-asylum.html.

Galvan, Astrid. 2019. "Asylum-seekers who crossed in Arizona returned to Mexico." Associated Press, December 6, 2019. https://apnews.com/article/2c5a6e1571c3a9224d551459abe50d03.

Heffron, Laurie. 2019. "Central American women fleeing violence experience more trauma after seeking asylum." PRI, April 25, 2019. https://www.pri.org/stories/2019-04-25/centralamerican-women-fleeing-violence-experience-more-trauma-after-seeking. 
Hennessy-Fiske, Molly. 2019. "Medical screenings are the latest U.S. tactic to discourage asylum seekers, advocates say." Los Angeles Times, December 10, 2019.

https://www.latimes.com/world-nation/story/2019-12-10/migrants-returned-to-mexicobarred-from-u-s-courts.

Hesson, Ted and David Shepardson. 2019. "U.S. Border Arrests Dropped Again in November Amid Trump Crackdown on Migrant Crossers." Reuters, December 9, 2019. https://www.reuters.com/article/us-usa-immigration-border-mexico/u-s-border-arrestsdropped-again-in-november-amid-trump-crackdown-on-migrant-crossersidUSKBN1YD2B9.

Hjelmgaard, Kim. 2019. "In news, when words fail, graphic and shocking photos often don't." USA Today, July 2, 2019.

https:/www.usatoday.com/story/news/world/2019/07/02/drowned-migrant-photo-oscaralberto-martinez-ramirez-daughter-valeria/1595000001/.

Human Rights First. 2021. "Delivered to Danger: Trump Administration sending asylum seekers and migrants to danger." Washington, DC: Human Rights First. https://www.humanrightsfirst.org/campaign/remain-mexico.

Human Rights Watch. 2017. "Q \& A: White House Immigration Principles and Policies." New York, NY: Human Rights Watch. https://www.hrw.org/news/2017/10/13/q-white-houseimmigration-principles-and-policies.

Human Rights Watch. 2019a. “'We Can’t Help You Here': US Returns of Asylum Seekers to Mexico.” New York, NY: Human Rights Watch. https://www.hrw.org/report/2019/07/02/we-cant-help-you-here/us-returns-asylumseekers-mexico.

Human Rights Watch. 2019b. "Mexico: Risks at Border for Those With Disabilities.” New York, NY: Human Rights Watch. https:/www.hrw.org/news/2019/10/29/mexico-risks-borderthose-disabilities.

Kahn, Carrie. 2019. "African Migrants Stuck In Mexico Plan To March Toward U.S." NPR, October 7, 2019. https://www.npr.org/2019/10/07/768032924/african-migrants-stuck-inmexico-plan-to-march-toward-u-s.

Kanno-Youngs, Zolan. 2019. "Death on the Rio Grande: A Look at a Perilous Migrant Route." New York Times, June 8, 2019. https://www.nytimes.com/2019/06/08/us/politics/migrants-drown-rio-grande.html.

Kao, Jason and Denise Lu. 2019. "How Trump's Policies Are Leaving Thousands of Asylum Seekers Waiting in Mexico.” New York Times, August 18, 2019. https://www.nytimes.com/interactive/2019/08/18/us/mexico-immigration-asylum.html.

Kiderra, Inga. 2019. "Remain in Mexico’ Asylum Seekers Face Numerous Risks." UC San Diego News Center, October 29, 2019. https://ucsdnews.ucsd.edu/pressrelease/remain-inmexico-asylum-seekers-face-numerous-risks.

Kids in Need of Defense. 2019. "What are the TVPRA Procedural Protections for Unaccompanied Children?” Washington, DC: Kids in Need of Defense. 
https://supportkind.org/wp-content/uploads/2019/04/KIND-TVPRA-talking-points4.1.19-FINAL.pdf.

Laird, Lorelei. 2019. "Strangers in a strange land: 'Metering' makes asylum rights meaningless, immigrant advocates say." Chicago, IL: American Bar Association Journal. https://www.abajournal.com/web/article/strangers-in-a-strange-land-human-rightsorganizations-say-metering-of-asylum-seekers-makes-asylum-rightsmeaningless\#: :text=Immigration\%20LawStrangers $\% 20$ in $\% 20 \mathrm{a} \% 20$ strange $\% 201$ and $\% 3 \mathrm{~A} \% 20$ 'Metering $\% 20$ makes $\% 20$ asylum,rig hts $\% 20$ meaningless $\% 2 \mathrm{C} \% 20$ immigrant $\% 20$ advocates $\% 20$ say\&text=Image $\% 20$ from $\% 20$ Shutterstock.com.\&text=The \%20plan $\% 20$ was $\% 20$ to\%20ask,get $\% 20$ on $\% 20 \mathrm{a} \% 20$ waiting \%20list.

Le Duc, Julia. 2019. "Salvadoreño y su hija mueren ahogados en intento por llegar a EU." $L a$ Jornada, June 24, 2019. https://lajornadasanluis.com.mx/nacional/salvadoreno-y-su-hijamueren-ahogados-en-intento-por-llegar-a-eu/.

Leahy, Senator Patrick. 2019. "Letter to Acting Secretary Chad Wolfe." Accessed March 23, 2021. https://www.leahy.senate.gov/imo/media/doc/Leahy\%20-\%20Letter $\% 20$ to $\% 20$ Acting $\% 20$ Sec. $\% 20$ Wolf $\% 20$ re $\% 20$ implementation $\% 20$ of $\% 20 \mathrm{MP}$ P\%20--\%20111919.pdf.

Leanos, Reynaldo. 2019. "Mexican Official Tries To Move Asylum-Seekers Stuck In Tent Camps." NPR, November 9, 2019. https://www.npr.org/2019/11/09/777686672/mexicanofficial-tries-to-move-asylum-seekers-stuck-in-tentcamps\#: : text=In $\% 20$ Matamoros $\% 2 \mathrm{C} \% 20 \mathrm{Mexic0} \% 2 \mathrm{C} \% 20$ more $\% 20$ than, asylum $\% 2 \mathrm{Dse}$ ekers $\% 20$ from $\% 20$ their $\% 20$ children.

Lind, Dara. 2019. "Exclusive: Civil servants say they're being used as pawns in a dangerous asylum program." Vox, May 2, 2019. https://www.vox.com/2019/5/2/18522386/asylumtrump-mpp-remain-mexico-lawsuit.

Margulies, Peter. 2019. "What Ending the Flores Agreement on Detention of Immigrant Children Really Means." Lawfare Blog, August 29, 2019. https://www.lawfareblog.com/what-ending-flores-agreement-detention-immigrantchildren-really-means.

Merchant, Nomaan. 2019.“Tents, stench, smoke: Health risks are gripping migrant camp.” Associated Press, November 14, 2019. https://apnews.com/article/337b139ed4fa4d208b93d491364e04da.

Merkley, Senator Jeff. 2019. Shattered Refuge. Washington, DC: Office of United States Senator Jeff Merkley. https://www.merkley.senate.gov/news/press-releases/merkley-releasessweeping-report-on-trumps-gutting-of-asylum-including-direct-evidence-of-gravewhistleblower-concerns-2019

Misra, Tanvi. 2019. “"Remain in Mexico' policy faces internal critiques at House hearing." Roll Call, November 19, 2019. https://www.rollcall.com/2019/11/19/remain-in-mexicopolicy-faces-internal-critiques-at-house-hearing/. 
Miroff, Nick. 2018. "Trump administration, seeking to speed deportations, to impose quotas on immigration judges." Washington Post, April 2, 2018.

https://www.washingtonpost.com/world/national-security/trump-administration-seekingto-speed-deportations-to-impose-quotas-on-immigration-judges/2018/04/02/a282d65036bb-11e8-b57c-9445cc4dfa5e story.html.

Montoya-Galvez, Camilo. 2019. "Advocates say "Remain in Mexico" policy turns migrants into a "marketable commodity." CBS News, August 15, 2019. https://www.cbsnews.com/news/remain-in-mexico-advocates-say-controversial-policyturns-migrants-into-a-marketable-commodity/.

Narea, Nicole. 2019. "Trump's agreements in Central America are dismantling the asylum system as we know it." Vox, September 26, 2019. https://www.vox.com/2019/9/26/20870768/trump-agreement-honduras-guatemala-elsalvador-explained.

National Immigration Forum. 2019. "Fact Sheet: U.S. Asylum Process.” Washington, DC: National Immigration Forum. https://immigrationforum.org/article/fact-sheet-u-sasylum-process/.

Nelson, Tamaryn and Hajar Habbach. 2019. " "If I went back, I would not survive.” Asylum Seekers Fleeing Violence in Mexico and Central America." Washington, DC: Physicians for Human Rights. https://phr.org/our-work/resources/asylum-seekers-fleeing-violencein-mexico-and-central-america/.

Montes, Aaron. 2019. "El Paso begins Trump policy that sends migrant asylum seekers back to Mexico." El Paso Times, March 16, 2019. https://www.elpasotimes.com/story/news/immigration/2019/03/16/trump-immigrationmetering-policy-migrant-protection-protocols-implemented-el-paso-juarez/3177682002/.

Ortiz, Gabe. 2019. "House Democrats condemn immigration 'tent courts' as 'shrouded in secrecy since their creation." Daily Kos, December 3, 2019. https://www.dailykos.com/stories/2019/12/3/1903289/-House-Democrats-condemnimmigration-tent-courts-as-shrouded-in-secrecy-since-their-creation.

Prendergast, Curt. 2019. “'Remain in Mexico' program begins in Nogales.” Tuscon.com, December 7, 2019. https://tucson.com/news/local/remain-in-mexico-program-begins-innogales/article 95f757ac-1851-11ea-b29e-47f1d679e3d8.html.

Rachko Jr., Thomas J. 2019. “US Should Cease Returning Asylum Seekers to Mexico.” New York, NY: Human Rights Watch. https://www.hrw.org/news/2019/11/25/us-shouldcease-returning-asylum-seekers-mexico.

Quinn, Melissa. 2021. "Supreme Court cancels arguments in two Trump-era immigration cases." CBS News, February 3, 2021. https://www.cbsnews.com/news/supreme-court-trumpimmigration-cases/.

Roldan, Riane. 2019. "Asylum seekers will appear before judges via teleconferencing in tents as "Remain in Mexico" program expands to Laredo." Texas Tribune, July 9, 2019. https://www.texastribune.org/2019/07/09/remain-mexico-program-expands-laredo-texas/. 
Root, Jay. 2019. "Trump administration to expand "remain in Mexico" policy to Brownsville." The Brownsville Herald, July 18, 2019. https://vela.house.gov/in-thenews? ID=21DCFC2C-A199-488B-9287-8682B00BDA9C.

Rose, Joel. 2019a."'Vulnerable' Migrants Should Be Exempt From 'Remain In Mexico,' But Many Are Not.” NPR, July 17, 2019. https://www.npr.org/2019/07/17/742271139/vulnerable-migrants-should-be-exemptfrom-remain-in-mexico-but-many-are-not.

Rose, Joel. 2019b. “'Remain In Mexico' Immigration Policy Expands, But Slowly.” NPR, March 12, 2019. https://www.npr.org/2019/03/12/702597006/-remain-in-mexico-immigrationpolicy-expands-but-slowly.

Sargent, Greg. 2019. "In scathing manifesto, an asylum officer blasts Trump's cruelty to migrants." Washington Post, November 12, 2019. https://www.washingtonpost.com/opinions/2019/11/12/scathing-manifesto-an-asylumofficer-blasts-trumps-cruelty-migrants/.

Schacher, Yael. 2019. “"Remain in Mexico" Is a Travesty of Asylum Policy.” Fair Observer, March 27, 2019. https://www.fairobserver.com/region/north america/remain-in-mexicoasylum-policy-dhs-us-border-news-00191/.

Sheridan, Mary Beth. 2019. "Cubans were once privileged migrants to the United States. Now they're stuck at the border, like everyone else." Washington Post, November 5, 2019. https://www.washingtonpost.com/world/cubans-were-once-privileged-migrants-to-theunited-states-now-theyre-stuck-at-the-border-like-everyone-else/2019/11/04/65fla4eafa60-11e9-9e02-1d45cb3dfa8f story.html.

Silva, Daniella. 2019. "Migrant families are being separated under remain-in-Mexico policy, complaint alleges." NBC News, August 20, 2019. https://www.nbcnews.com/news/usnews/migrant-families-are-being-separated-under-remain-mexico-policy-complaint$\underline{\mathrm{n} 1044466 .}$.

Southern Poverty Law Center. 2019. "The Attorney General's Judges: How the U.S. Immigration Courts Became a Deportation Tool.” Montgomery, Alabama: Southern Poverty Law Center. https://www.splcenter.org/20190625/attorney-generals-judges-how-usimmigration-courts-became-deportation-tool.

Srikrishnan, Maya. 2019. "Bureaucratic Tensions Over 'Remain in Mexico' Keep Boiling Into Public View.” Voice of San Diego, October 17, 2019. https://www.voiceofsandiego.org/topics/government/bureaucratic-tensions-over-remainin-mexico-keep-boiling-into-public-view/.

Stevenson, Mark. 2018. "US pledges \$10.6B aid for Central America, southern Mexico." Associated Press, December 18, 2018. https://apnews.com/article/0fcda32812024680ad98676379c47233.

Suarez Sang, Lucia. 2019. “'Tent courts' set up at border towns to ease strain on immigration cases." Fox News, September 13, 2019. https://www.foxnews.com/us/text-courtimmigration-border-texas. 
Transactional Records Access Clearinghouse at Syracuse University (TRAC). 2021. "Details on MPP (Remain in Mexico) Deportation Proceedings.” Syracuse, NY: Transactional Records Access Clearinghouse. https://trac.syr.edu/phptools/immigration/mpp/.

TRAC. 2019a. "Incomplete and Garbled Immigration Court Data Suggest Lack of Commitment to Accuracy." Syracuse, NY: Transactional Records Access Clearinghouse. https://rac.syr.edu/immigration/reports/580/.

TRAC. 2019c. "Crushing Immigration Judge Caseloads and Lengthening Hearing Wait Times." Syracuse, NY: Transactional Records Access Clearinghouse. https://trac.syr.edu/immigration/reports/579/\#: : text=Projected $\% 20$ average $\% 20 \mathrm{wait} \% 20 \mathrm{t}$ imes $\% 20$ have, out $\% 20$ as $\% 20$ December $\% 2018 \% 2 \mathrm{C} \% 202023$.

TRAC. 2019d. "Access to Attorneys Difficult for Those Required to Remain In Mexico." Syracuse, NY: Transactional Records Access Clearinghouse. https://trac.syr.edu/immigration/reports/568/\#: :text=Remain\%20In\%20Mexico,Access $\% 20$ to\%20Attorneys \%20Difficult $\% 20$ for $\% 20$ Those $\% 20$ Required $\% 20$ to $\% 20$ Rem ain $\% 20$ In,program $\% 20$ has $\% 20$ been $\% 20$ expanding $\% 20$ rapidly.

TRAC. 2019e. "Most Released Families Attend Immigration Court Hearings." Syracuse, NY: Transactional Records Access Clearinghouse. https://rac.syr.edu/immigration/reports/562/.

TRAC. 2018. “Immigration Court Backlog Surpasses One Million Cases.” Syracuse, NY: Transactional Records Access Clearinghouse. https://rac.syr.edu/immigration/reports/574/\#: : text=The\%20Immigration $\% 20$ Court's $\% 2$ 0active $\% 20$ backlog,passed $\% 20$ the $\% 20$ million $\% 20$ case $\% 20$ mark.\&text $=$ If $\% 20$ the $\% 20$ ad ditional $\% 20322 \% 2$ C535\%20cases, backlog $\% 20$ now $\% 20$ tops $\% 201.3 \% 20$ million.

Trovall, Elizabeth. 2019. "'Metering' Policy at The Southern Border Faces Renewed Scrutiny." NPR, July 3, 2019. https:/www.npr.org/2019/07/03/738586876/metering-policy-at-thesouthern-border-faces-renewed-scrutiny.

United Nations. 2019. "Universal Declaration of Human Rights.” Accessed March 23, 2021. https://www.un.org/en/universal-declaration-human-rights/.

United States Department of State. 2019a. "U.S.-Mexico Joint Declaration.” Washington, DC: United States Department of State. https://www.state.gov/wpcontent/uploads/2019/09/19-607-Mexico-Migration-and-Refugees.pdf.

United States Department of State. 2019b. "Mexico Travel Advisory.” Washington, DC: United States Department of State. https://ravel.state.gov/content/travel/en/traveladvisories/traveladvisories/mexico-traveladvisory.html.

United States Department of Justice (DOJ) Executive Office for Immigration Review (EOIR). 2019a. "About the Office." Washington, DC: United States Department of Justice. https://www.justice.gov/eoir/about-office.

United States DOJ EOIR. 2019b. "Executive Office for Immigration Review Director James McHenry Testifies Before the Senate Committee on Homeland Security and 
Governmental Affairs." Washington, DC: United States Department of Justice. https://www.justice.gov/opa/speech/executive-office-immigration-review-director-jamesmchenry-testifies-senate-committee.

United States DOJ EOIR. 2019c. "Immigration Judge Hiring." Washington, DC: United States Department of Justice. https://www.justice.gov/eoir/page/file/1104846/download.

United States DOJ EOIR. 2019d. "Myths vs Facts About Immigration Proceedings." Washington, DC: United States Department of Justice. https://www.justice.gov/eoir/page/file/1161001/download.

United States EOJ EOIR. 2019e. "Executive Office of Immigration Review Announces Case Completion Numbers for Fiscal Year 2019." Washington, DC: United States Department of Justice. https://www.justice.gov/eoir/page/file/1161001/download.

United States DOJ EOIR. 2018. "Statistics Yearbook Fiscal Year 2018." Washington, DC: United States Department of Justice. https://www.justice.gov/opa/pr/executive-officeimmigration-review-announces-case-completion-numbers-fiscal-year-2019.

United States DOJ EOIR. 2017. "Statistics Yearbook Fiscal Year 2017.” Washington, DC: United States Department of Justice. https://www.documentcloud.org/documents/6024661-Statistics-Yearbook-Fiscal-Year2017-US.html.

United States Government Accountability Office (GAO). 2018. "Immigration Courts: Observations on Restructuring Options and Actions Needed to Address Long-Standing Management Challenges.” Washington, DC: United States Government Accountability Office. https://www.gao.gov/assets/700/691343.pdf.

House Homeland Security Committee Border Security, Facilitation, \& Operations of the 116th Congress. 2019. "Examining the Human Rights and Legal Implications Of DHS' 'Remain in Mexico' Policy." Washington, DC: United States Congress. https://homeland.house.gov/activities/hearings/examining-the-human-rights-and-legalimplications-of-dhs-remain-in-mexico-policy.

Washington Post. 2019. "Federal judge ruling on Migrant Protection Protocols." Washington Post, April 8, 2019.

https://www.washingtonpost.com/context/federal-judge-ruling-on-migrant-protectionprotocols/900c94f3-53a5-4052-93f0-a49738dabaa6/.

Wong, Tom. 2019. Seeking Asylum: Part 2. La Jolla, California: US Immigration Policy Center. https://usipc.ucsd.edu/publications/usipc-seeking-asylum-part-2-final.pdf. 